\title{
Implications of field relations and U-Pb geochronology for the age of gold mineralization and timing of Acadian deformation in northern New Brunswick
}

\author{
Steven R. McCutcheon \\ Department of Natural Resources and Energy, Geological Surveys Branch, 495 Riverside Drive, \\ Bathurst, New Brunswick E2A 3Z1, Canada
}

and Mary Lou Bevier
Geological Survey of Canada, 601 Booth Street, Ottawa, Ontario K1A OE8, Canada

Date Received May 22, 1990

Date Accepted October 9, 1990

\begin{abstract}
In the Upsalquitch Forks area (NTS $210 / 10)$, penetratively deformed sedimentary and volcanic rocks of the Silurian Chaleurs Group and Lower Devonian Dalhousie and Tobique groups were intruded by abundant syn-to post-tectonic dykes and plugs. The Mulligan Gulch porphyry, a hypabyssal felsic intrusion (with an extrusive component ?) emplaced in Upper Silurian sedimentary rocks, has yielded a U-Pb zircon age of $419 \pm 1 \mathrm{Ma}$, whereas the Jerry Ferguson porphyry, a felsic intrusion that intruded Lower Devonian volcanic rocks, has yielded a U-Pb zircon age of $401 \pm 1 \mathrm{Ma}$.

The above ages, combined with field relationships, permit the following conclusions: (1) felsic and mafic intrusions in the Upsalquitch Forks area are more or less coeval with volcanic rocks of the Chaleurs, Dalhousie and Tobique groups; (2) most gold occurrences in the area are genetically related to mafic intrusions and, therefore, formed in Late Silurian to Early Devonian time; (3) penetrative deformation in the area was predominantly a Silurian rather than a Devonian process and therefore was not Acadian sensu stricto; (4) Late Silurian to Early Devonian igneous activity occurred in a compressive, rather than an extensional, tectonic setting.
\end{abstract}

Dans la région d'Upsalquitch Forks (SNRC $210 / 10$ ), les roches sédimentaires et volcaniques à déformation pénétrative du Groupe de Chaleurs (Silurien) et des groupes de Dalhousie et de Tobique (Dévonien inférieur) sont recoupées par d'abondants dykes et culots syn- à post-tectoniques. Le porphyre de Mulligan Gulch, une intrusion felsique hypoabyssale (dotée d'une composante extrusive?) emplacée au sein de roches sédimentaires du Silurien supérieur, a livré un âge U-Pb sur zircons de 419 $\pm 1 \mathrm{Ma}$. En revanche, le porphyre de Jerry Ferguson, une intrusion felsique au sein de volcanites du Dévonien inférieur, a livré un âge U-Pb sur zircons de $401 \pm 1 \mathrm{Ma}$.

Ces âges, combinés aux relations observées sur le terrain, permettent de conclure que: (1) les intrusions felsiques et mafiques dans la région d'Upsalquitch sont plus ou moins synchrones des volcanites des groupes de Chaleurs, Dalhousie et Tobique; (2) la plupart des gîtes auriferes de cette région sont reliés par leur genèse aux intrusions mafiques et, par conséquent, ils se sont formés du Silurien tardif au début du Dévonien; (3) la déformation pénétrative dans cette région eût lieu surtout au Silurien plutôt qu'au Dévonien, et elle n'est donc pas acadienne au sens strict; (4) l'activité ignée tardisilurienne à éodévonienne survint dans un régime tectonique de compression plutôt que d'extension.

[Traduit par le joumal]

\section{INTRODUCTION}

The Upsalquitch Forks map area (NTS $210 / 10$ ) is situated in the central part of northern New Brunswick, about $90 \mathrm{~km}$ west of the city of Bathurst (Fig. 1). This area is predominantly underlain by Upper Ordovician to Lower Devonian strata that were variably deformed during the Acadian Orogeny and intruded by numerous syn-to post-tectonic dykes and plugs of both mafic and felsic compositions. The area is also cut by several major faults, the main one being the Rocky Brook - Millstream Fault (RBMF).

In the early 1980's, a number of low-grade gold occurrences, with associated iron-carbonate alteration, were discovered south of the RBMF. Initially these occurrences were thought to be related to the RBMF and related splays, but subsequently they were attributed to intrusions that were emplaced along these major faults zones (Pronk and Burton, 1988; Ruitenberg et al., 1990). However, there is good evidence that some of the faulting 


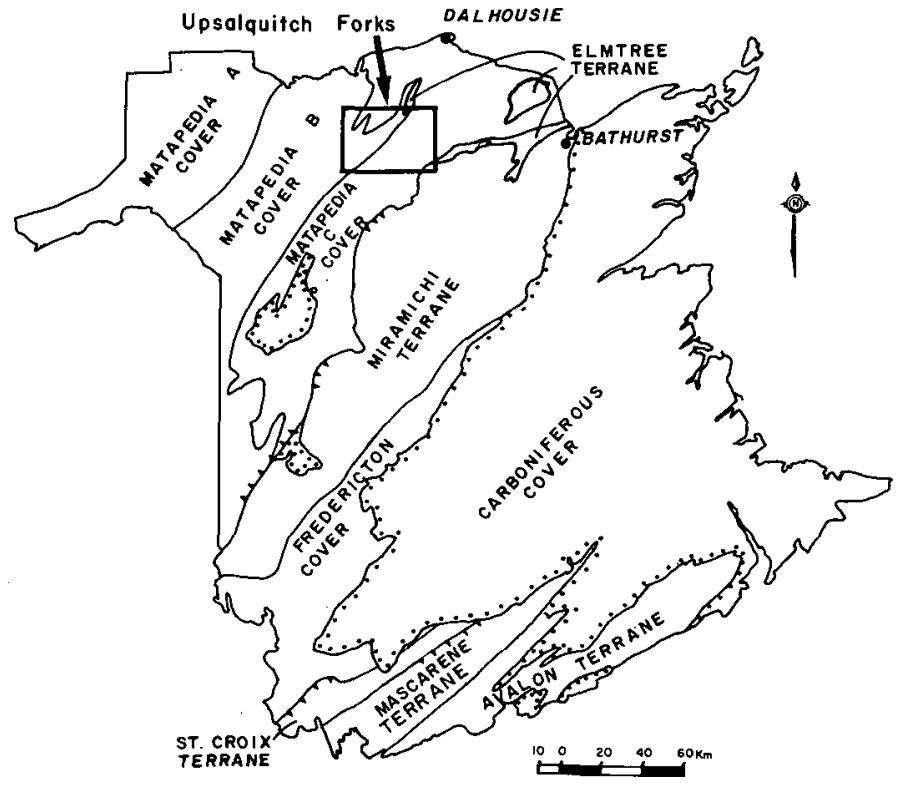

Fig. 1. Terrane map of New Brunswick (after Fyffe and Fricker, 1987) showing the location of the Upsalquitch Forks map area.

post-dated the gold mineralization and that many of the intrusions are remote from fault zones (Walker and McCutcheon, 1991). The age of the gold mineralization, until now, was considered to be early Middle Devonian or younger (Ruitenberg et al., 1990).

The purposes of this paper are: (1) to briefly describe the geologic setting of the Upsalquitch Forks area; (2) to report two new U-Pb zircon ages from felsic porphyries; and (3) to show how these ages constrain the timing of plutonism, deformation and gold mineralization in northern New Brunswick.

\section{REGIONAL GEOLOGIC SETTING}

The Upsalquitch Forks map area straddles four major tectono-stratigraphic belts (Fig. 1). From southeast to northwest these belts are: the Miramichi Terrane, the Matapedia C Cover, the Elmtree Terrane, and the Matapedia B Cover.

Miramichi Terrane is underlain by the Miramichi and Tetagouche groups, which are correlated with the Gander and Dunnage zones of Newfoundland, respectively (van Staal and Fyffe, in press; van Staal and Langton, 1990a, b). The Miramichi Group is a quartzite-slate sequence of turbiditic origin and Cambrian to Early Ordovician (Arenigian) age. The Tetagouche Group consists of epiclastic and felsic volcanic rocks with some basalt, greywacke, slate and chert. It ranges in age from Middle to Late Ordovician (Llandvimian to Caradocian).

Elmtree Terrane comprises two groups of rocks from three geographically separate areas (Fig. 1). In the northeastern and southern areas, this terrane is made up of the Fournier Group including the recently introduced Millstream and Sormany formations of van Staal and Langton (1990a, b). The Elmtree Group was formerly considered part of this terrane (Fyffe and Fricker, 1987), but has been reduced to formation status and assigned to the Tetagouche Group (van Staal and Langton, 1990a, b). The
Fournier Group consists of a mafic to ultramafic intrusive complex that is overlain by pillow basalt, greywacke, slate and minor limestone. Graptolites from the slate are early Caradocian (Fyffe, 1986) but the intrusive complex has yielded Llandeilian U-Pb ages (Spray et al., 1990 and van Staal et al., 1988). In the northwestern area, Elmtree Terrane is made up of the Balmoral Group, a name introduced by Philpott (1988), which consists of a lower andesitic to picritic volcanic unit and an upper graptolitic slate-chert unit. The latter unit is identical in age (Caradocian) and lithology to rocks near the top of the Foumier and Tetagouche groups.

The Matapedia B Cover is a conformable sedimentary sequence that ranges in age from Late Ordovician to Early Silurian, which includes the Grog Brook and Matapedia groups. The Grog Brook Group (Honorat Group in Quebec) is a turbidite sequence that consists of wacke, siltstone and conglomerate, whereas the Matapedia Group comprises interbedded limestone and calcareous shale (St. Peter, 1978a).

The Matapedia C Cover is composed of Early Silurian to Early Devonian sedimentary and volcanic rocks that host most of the gold occurrences. These rocks are described in detail below.

\section{STRATIGRAPHY OF THE UPSALQUITCH FORKS MAP AREA}

The stratigraphy in the Upsalquitch Forks map area (Fig. 2), which is mainly underlain by the Chaleurs, Dalhousie and Tobique groups of the Metapedia $C$ Cover, differs north and south of the Rocky Brook - Millstream Fault (RBMF), as shown in Table 1. The Tobique Group only occurs south of the RBMF, whereas the Dalhousie Group is restricted to the area north of this fault. The Chaleurs Group occurs on both sides of the fault but has a significant volcanic component only north of the fault.

\section{Chaleurs Group}

In the type area, which is between Port Daniel and Gascons along the Gaspe coast of Quebec, this group comprises eight formations (Table 1) and ranges in age from Early Llandoverian to Pridolian (Bourque and Lachambre, 1980; Bourque, 1987). In the Upsalquitch Forks map area and north of the RBMF, the Chaleurs Group is composed of four formations. In ascending stratigraphic order they are: Upsalquitch, La Vieille, Bryant Point and Benjamin (Table 1, Fig. 2). The first two units are entirely sedimentary whereas the last two units are mainly composed of volcanic rocks. The Upsalquitch Formation is a fine-grained clastic unit, whereas the La Vieille Formation is predominantly limestone. The Bryant Point and Benjamin formations are of interest because they constitute a volcanic pile that is co-magmatic with the intrusive rocks.

The Bryant Point Formation, which was defined by Greiner (1967), is mainly composed of dark greyish green to maroon, massive, amygdaloidal and porphyritic basalt. However, there are also some intercalated felsic volcanic rocks and in one locality a cobble conglomerate occurs at the base. A lower age limit for the Bryant Point is provided by the underlying La Vieille Formation, a unit that is not older than Llandoverian C6 and not 
younger than Wenlockian (Lee and Noble, 1977).

The Benjamin Formation, also defined by Greiner (1967), directly overlies the Bryant Point Formation and is dominated by pale red, flow-banded, sparsely porphyritic rhyolite. However, this formation also includes feldspar crystal tuff, pumiceous lapilli tuff and, near the top, a mafic volcanic unit. An upper age limit for the Benjamin Formation is given by the fossiliferous Lower Devonian Dalhousie Group.

South of the RBMF the Chaleurs Group consists of the Simpsons Field, LaPlante, Budworm City, and Greys Gulch formations in ascending stratigraphic order (Table 1, Fig. 2). The first two formations are mainly coarse-grained clastic rocks and limestone, respectively. The last two formations are important because they host most of the gold occurrences. Furthermore, the Greys Gulch Formation hosts one of the dated intrusions.

The Budworm City Formation (Walker and McCutcheon, 1991) consists of grey to black siltstone and fine- to mediumgrained sandstone with minor conglomerate and limestone. This unit appears to conformably overlie limestone of the LaPlante Formation that contains conodonts of Pridolian to Early Devonian age (Nowlan, written communication, 1988).

The Greys Gulch Formation (Walker and McCutcheon, 1991) is predominantly a redbed unit composed of greyish red and locally greenish grey siltstone and fine-grained sandstone. In the western part of the map area, the Greys Gulch Formation appears to be gradationally overlain by greenish grey siltstone of the Lower Devonian Tobique Group. The Silurian-Devonian boundary is arbitrarily placed at the top of this formation because redbeds occur near the top of the Silurian sections in Gaspé (Indian Point Formation) and in southeastern Maine (Hersey Formation).

\section{Tobique Group}

In the type area this group, which was named and described by St. Peter (1978b), consists of a lower, predominantly felsic, volcanic unit called the Costigan Mountain Formation and an upper unit of mafic volcanic and sedimentary rocks called the Wapske Formation. In the map area, this group is undivided and largely composed of greenish grey siltstone and sandstone with some mafic and a few felsic volcanic rocks. Pillow lavas occur locally. A few fossil localities confirm the Early Devonian (Gedinnian) age reported for the group in the type area (St. Peter, 1978b; Wilson, 1990).

\section{Dalhousie Group}

This group, which was named by Clarke (1909) and subdivided by Greiner (1967), includes silty limestone and mudstone of the Louison Creek Formation, mafic volcanic rocks of the Sunnyside Formation, calcareous mudstone and limestone of the Jacquet River Formation and felsic volcanic rocks of the Archibald Settlement Formation, in ascending stratigraphic order. Fossils in the Louison Creek indicate an Early Devonian age.

In the map area, greenish grey to dark grey siltstone and sandstone predominate in the lower part of the group and locally the base is marked by a conglomerate containing fossil debris.
Mafic volcanic rocks, in places pillowed, are abundant in the upper part. Felsic pyroclastic rocks are intercalated throughout the group but they constitute a minor component. Spores from the sedimentary rocks indicate an Early Devonian (Gedinnian to Siegenian) age (McGregor, written communication, 1989).

The Campbellton Formation (Ami, 1900), which is equivalent to the La Garde Formation (Dineley and Williams, 1968) in Quebec, unconformably overlies the Dalhousie Group. This formation consists of fluvial rocks that are Middle Devonian (Emsian to Eifelian) in age (McGregor, 1961; Andrews et al., 1975). Greenish grey, medium-grained sandstone and pebble to granule conglomerate, in the eastern part of the Upsalquitch Forks area, have been assigned to this formation. The conglomerate contains abundant volcanic pebbles derived from the Chaleurs and/or Dalhousie groups and a few clasts of hypabyssal intrusive rocks analagous to the La Garde Formation (cf. Rust $e t$ al., 1990). The presence of clasts from hypabyssal intrusions in the Campbellton Formation demonstrate that at least some intrusions in the area are pre-Middle Devonian.

\section{INTRUSIVE ROCKS}

Numerous mafic and felsic intrusions occur in the Upsalquitch Forks map area and range in type and size from dykes $1 \mathrm{~m}$ wide to plutons a few kilometers across (Fig. 2). These intrusions are particularly common in Silurian and older strata. Mafic intrusions are most abundant south of the RBMF whereas felsic ones are abundant north of this fault.

The mafic intrusions consist of fine- to medium-grained gabbro and diorite and they are commonly plagioclase porphyritic. Many of the small intrusions are sub-parallel to the regional foliation and a few actually have a poorly developed cleavage near their margins (Ruitenberg et al., 1989). The margins of some intrusions exhibit pervasive iron-carbonate alteration and the adjacent, penetratively deformed, country rocks are brecciated; other intrusions display only minor alteration effects (Murphy, 1989). In places, unaltered intrusions appear to cut the altered ones (Mitton, 1988; Adair, 1989). Gold occurrences are spatially associated with intrusions that display iron-carbonate alteration. Murphy (1989) suggested that the mafic intrusions were largely comagmatic with the Siluro-Devonian volcanism because of geochemical similarities between the intrusive rocks and mafic lavas of the Dalhousie and Tobique groups. The fact that mafic intrusions rarely cut the Lower Devonian volcanic pile is compatible with this interpretation.

The felsic intrusions are leucocratic microgranites and porphyries that are commonly feldspar porphyritic but rarely quartz porphyritic (Brewer et al., 1991). Miarolitic cavities occur in many of the microgranites indicating their hypabyssal nature. Some exhibit effects of argillic and silicic alteration. Most are syn- to post-tectonic because they either cut rocks with cleavage or are aligned parallel to regional foliation. Chemically these intrusions range in composition from rhyodacite to high silica rhyolite (Brewer et al., 1991).

The Mulligan Gulch porphyry, one of the radiometrically dated intrusions, is situated near the contact between the Greys Gulch and Budworm City formations (Fig. 2, Unit D). The 


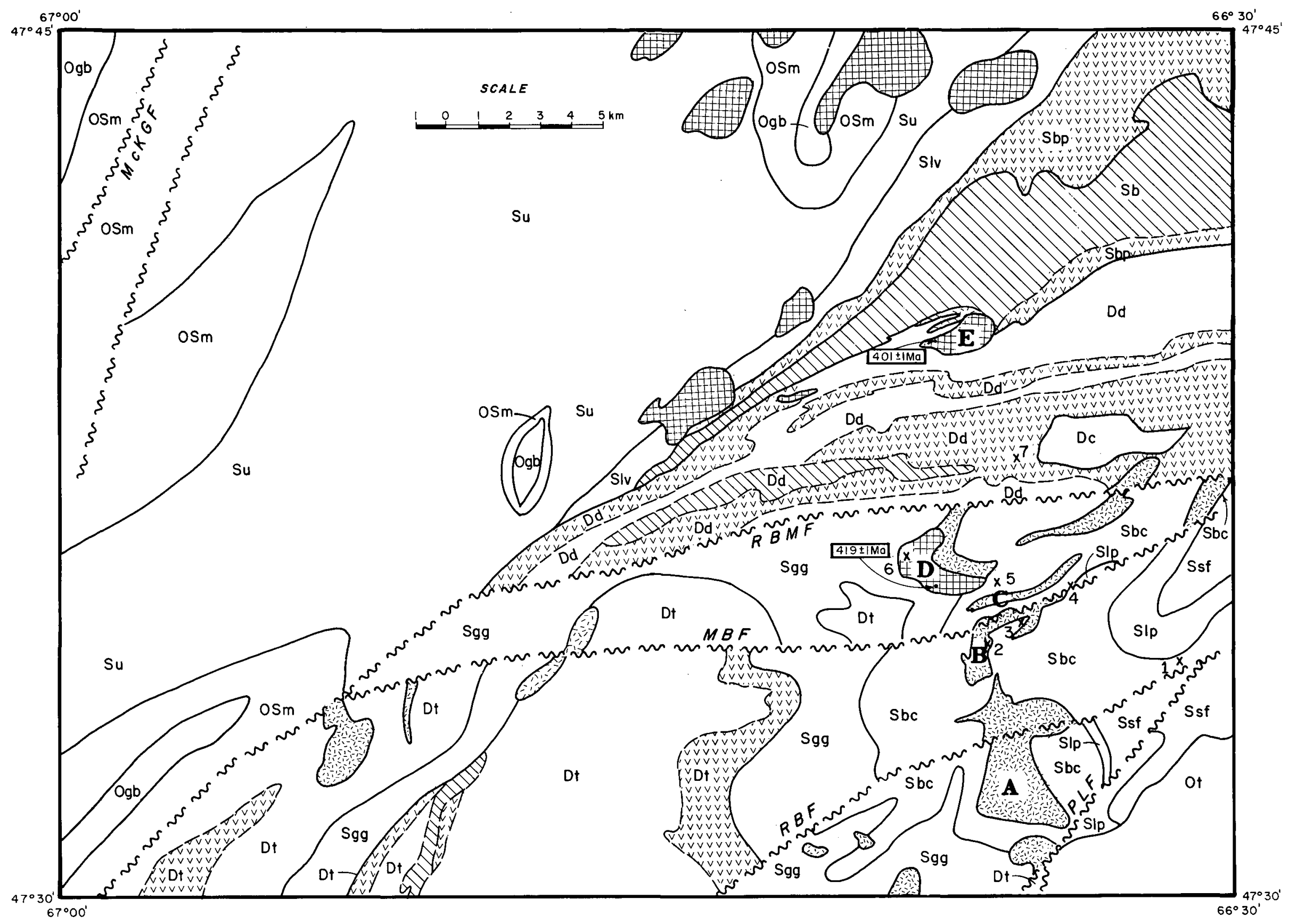

Fig. 2a. Simplified geology map of the Upsalquitch Forks map area (NTS $21 \mathrm{O} / 10$ ). 
SOUTH OF RBMF

LOWER DEVONIAN TO UPPER SILURIAN

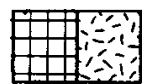

Felsic and mafic intrusions

LOWER DEVONIAN

Dt TOBIQUE GP.

UPPER SILURIAN

\begin{tabular}{|l|l} 
Sgg & GREYS GULCH FM. \\
SbC & BUDWORM CITY FM. \\
Slp & LAPLANTE FM. \\
\cline { 1 - 1 } SSf & SIMPSONS FIELD FM.
\end{tabular}

MIDDLE TO UPPER ORDOVICIAN

ot TETAGOUCHE GP.

SYMBOLS

- Contact

monn Fault

vvvvvvv Mafic volcanic rocks

M Felsic volcanic rocks

A. Named intrusion

1. Gold occurrence

$419 \pm 1 \mathrm{Ma}$ Radiometric age

\section{FAULTS}

PLF Portage Lakes fault

RBF Ramsay Brook fault

MBF McCormack Brook fault

RBMF Rocky Brook - Millstream fau

MCKGF McKenzie Gulch fault
NORTH OF RBMF

MIDDLE DEVONIAN

DC

CAMPBELLTON FM.

LOWER DEVONIAN TO UPPER SILURIAN

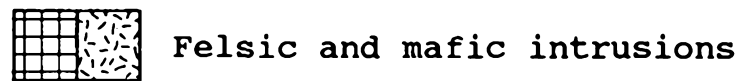

LOWER DEVONIAN

Dd DALHOUSIE GP.

UPPER SILURIAN

$\mathrm{Sb}$

BENJAMIN FM.

SbP BRYANT POINT FM.

LOWER SILURIAN

SIV LaVIEILLE FM.

SU UPSALQUITCH FM.

UPPER ORDOVICIAN TO LOWER SILURIAN

OSm MATAPEDIA GP.

MIDDLE TO UPPER ORDOVICIAN

Ogb GROG BROOK Or BALMORAL GP.

\section{NAMED GOLD OCCURRENCES}

1. Simpsons Field

2. Jonpol

3. McCormack Brook

4. McCormack Brook East

5. Dalhousie Road

6. Mulligan Gulch

7. Upsalquitch Forks

NAMED INTRUSIONS

A. Ramsay Brook Pluton

B. McCormack Brook Pluton

C. Dalhousie Road Pluton

D. Mulligan Gulch Porphyry

E. Jerry Ferguson Porphyry 
Table 1. Stratigraphic columns for the type areas of the Chaleurs, Tobique and Dalhousie groups compared to stratigraphic columns north and south of the Rocky Brook - Millstream Fault (RBMF).

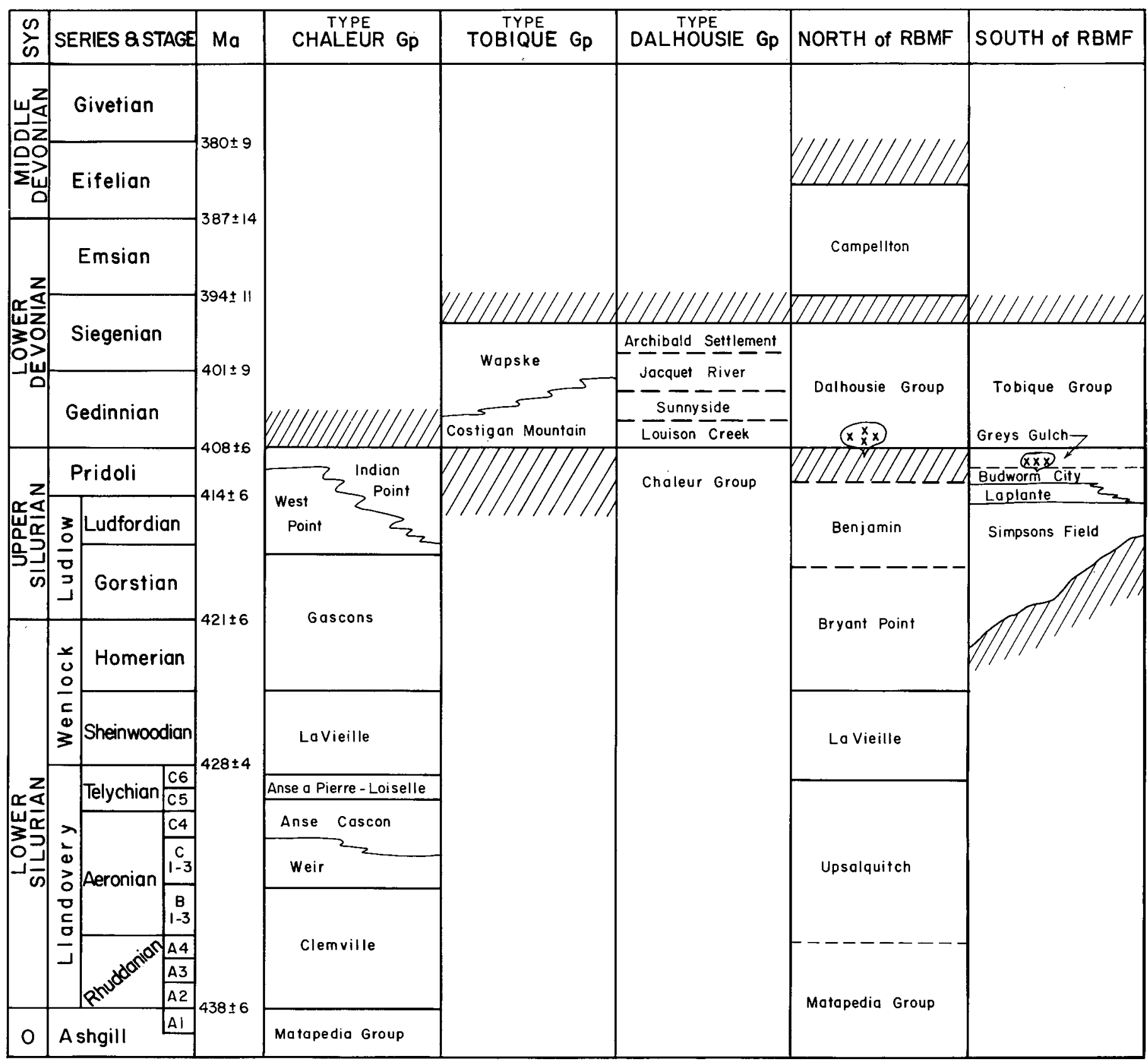

northern part of this body is intrusive and displays a microcrystalline groundmass but to the south the groundmass is cryptocrystalline suggesting a very high-level sill or extrusion. The rocks are feldspar ( \pm quartz) porphyritic throughout. The dated sample is pale red to pale yellowish brown and contains $15-20 \%$ subhedral feldspar phenocrysts $(0.5-5 \mathrm{~mm})$ in a cryptocrystalline groundmass (Fig. 3a, b). The intrusive aspect of the northern part of this porphyry has been demonstrated by diamond drilling (Fitzpatrick, 1986) near gold occurrence \#6 (Fig. 2).

The Jerry Ferguson porphyry, the other dated intrusion, is located near the contact between the Chaleurs and Dalhousie groups and intruded Lower Devonian (Gedinnian) strata (Fig. 2, Unit E). The rocks are feldspar porphyritic with a microcrystalline to fine-grained groundmass. Where the dated sample was collected (Appendix 1), the rock is reddish brown with 20-25\% subhedral feldspar phenocrysts and glomerocrysts, plus $1-2 \%$ anhedral quartz phenocrysts (1-2.5 $\mathrm{mm}$ ), in a very fine-grained crystalline groundmass (Fig. 4a, b).

\section{U-Pb GEOCHRONOLOGY}

\section{Analytical techniques}

Zircons were separated from $25 \mathrm{~kg}$ of each rock sample, and individual zircon populations were isolated initially on the basis of grain size and magnetic susceptibility and subsequently by crystal habit. Grains selected for analysis were hand picked using a binocular microscope to find the most euhedral, optically 

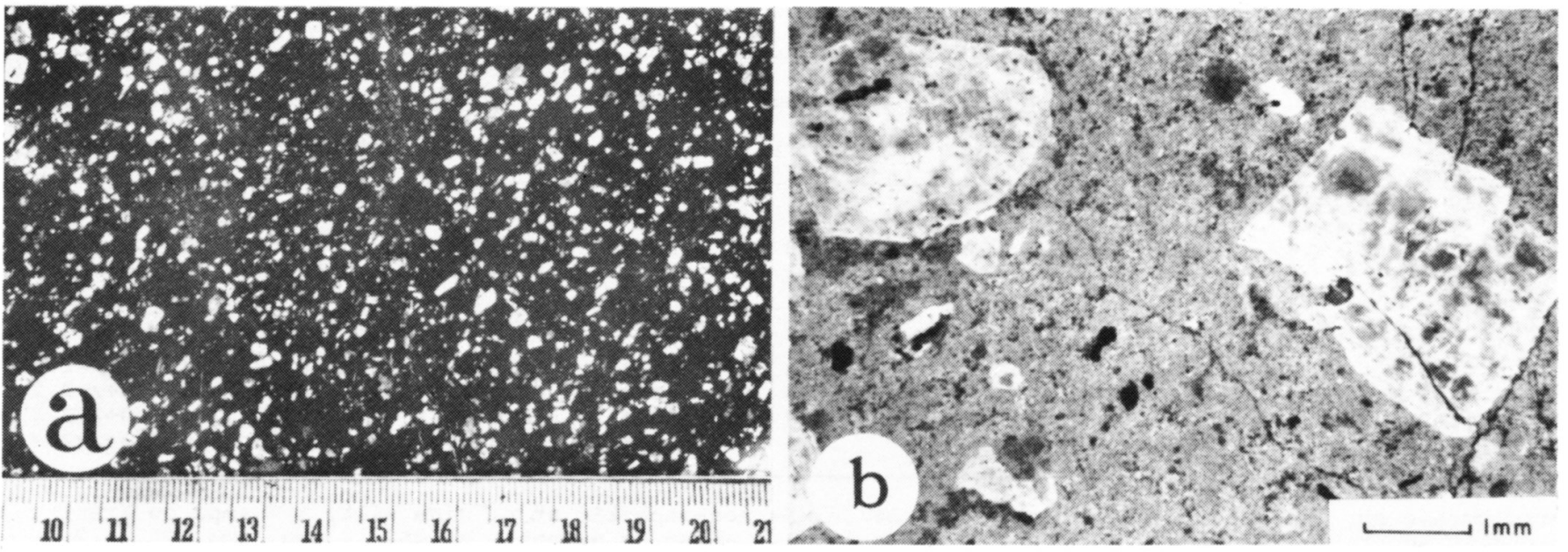

Fig. 3 (a) Photograph of sawn slab from Mulligan Gulch porphyry. Small divisions on scale are millimeters. (b) Micrograph of Mulligan Gulch porphyry. Plane light. Note the cryptocrystalline groundmass.
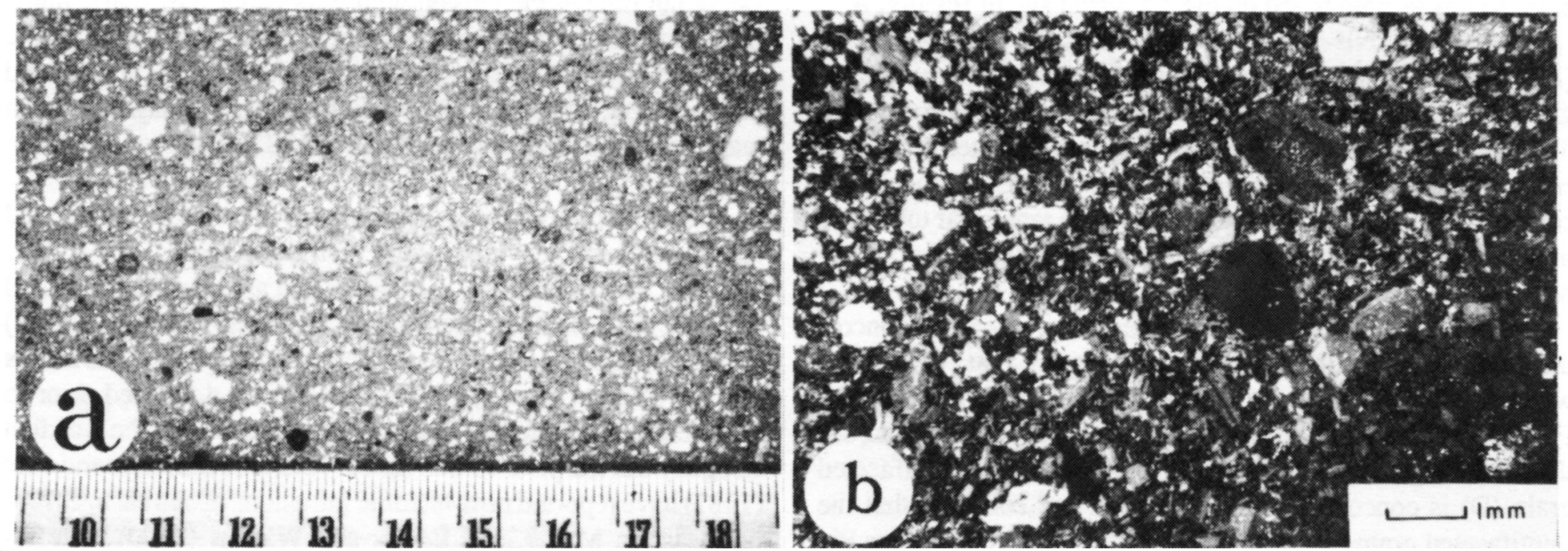

Fig. 4 (a) Photograph of sawn slab from Jerry Ferguson porphyry. Small divisions on scale are millimeters. (b) Micrograph of Jerry Ferguson porphyry. Cross-polarized light. Note the microcrystalline groundmass.

homogeneous, fracture-free and inclusion-free grains. All zircon fractions were abraded to remove potentially altered outer parts of the grains (Krogh, 1982).

Several fractions of zircon were analyzed from each sample. Procedures for dissolution, separation of $\mathrm{Pb}$ and $\mathrm{U}$, and purification techniques employing a ${ }^{205} \mathrm{~Pb} /{ }^{233-235} \mathrm{U}$ spike were the same as those detailed in Parrish et al. (1987). Total procedural blanks for $\mathrm{Pb}$ ranged from 5 to $21 \mathrm{pg}$ (average $10 \mathrm{pg} ; \mathrm{n}=6$ ). U blanks averaged $2 \mathrm{pg}$. Discordia line intercepts and associated errors were calculated using a modified York technique as detailed in Parrish et al. (1987). Errors were propagated numerically (Roddick, 1987) and are quoted at the 2 sigma level, with ${ }^{20} \mathrm{~Pb} /{ }^{235} \mathrm{U}$ and ${ }^{206} \mathrm{~Pb} /{ }^{23} \mathrm{U}$ errors averaging 0.23 and $0.18 \%$, respectively. Common $\mathrm{Pb}$ corrections were uniformly very low and compositions assumed were those given by the model of Stacey and Kramers (1975) at $400 \mathrm{Ma}$. All age determinations were calculated using the decay constants of Steiger and Jäger (1977). Some analyses generated in this study fall on or near concordia. We consider an analysis to be concordant when there is a substantial overlap of the 2 sigma error envelope with concordia. For such analyses, the error we assign to the crystallization age is the 2 sigma error of the ${ }^{206} \mathrm{~Pb} /{ }^{235} \mathrm{U}$ age. The geological time scale of Palmer (1983) is used throughout this paper.

\section{Results}

U-Pb analytical data are given in Table 2. Sample MLNB739 is from the Mulligan Gulch porphyry (Appendix 1, Fig. 2). Zircons from this sample are pale yellow, euhedral to rounded grains with length:breadth (1:b) of 1.5:1 and good to excellent clarity. The grains show no zoning or visible cores and inclusions of clear tubes, bubbles, and opaque specks (probably ilmenite) are rare (fraction A) to common (fraction B). The rounded grains do not show evidence of pitting or frosting and likely formed as a result of igneous resorption.

Two fractions of zircon from MLNB-739 plot on or near 
Table 2. U-Pb analytical data.

\begin{tabular}{|c|c|c|c|c|c|c|c|c|}
\hline Zircon fraction & $\begin{array}{l}\text { Weight } \\
\text { (mg) }\end{array}$ & $\begin{array}{c}\mathrm{U} \\
(\mathrm{ppm})\end{array}$ & $\begin{array}{c}\mathrm{Pb}^{\star} \\
(\mathrm{ppm})\end{array}$ & $\begin{array}{c}\text { Measured } \\
{ }^{206} \mathrm{~Pb} /{ }^{204} \mathrm{~Pb}\end{array}$ & \multirow[t]{2}{*}{$\begin{array}{c}{ }^{208} \mathrm{~Pb}^{\star} \\
(\%)\end{array}$} & \multicolumn{2}{|c|}{$\begin{array}{c}\text { Isotopic ratios } \\
{ }^{206} \mathrm{~Pb}^{\star} / 238 \mathrm{U}{ }^{207} \mathrm{~Pb}^{\star} / 235 \mathrm{U}\end{array}$} & \multirow[t]{2}{*}{$\begin{array}{c}{ }^{207} \mathrm{~Pb}^{\star} / 206 \mathrm{~Pb}^{\star} \\
\text { Age (Ma) }\end{array}$} \\
\hline MLNB-739, Mulliga & Gulch por & hyry & & & & & & \\
\hline $\begin{array}{ll}\text { A. } & \mathbf{W}+105 \mathrm{~A} \\
\text { B. } & \mathrm{M}+105 \mathrm{~A}\end{array}$ & $\begin{array}{l}0.0265 \\
0.0776\end{array}$ & $\begin{array}{l}262.5 \\
323.1\end{array}$ & $\begin{array}{l}20.59 \\
25.48\end{array}$ & $\begin{array}{l}1488 \\
3351\end{array}$ & $\begin{array}{l}22.3 \\
22.9\end{array}$ & $\begin{array}{l}0.06710 \\
0.06693\end{array}$ & $\begin{array}{l}0.51061 \\
0.50904\end{array}$ & $\begin{array}{l}419.9+/-3.1 \\
418.9+/-1.9\end{array}$ \\
\hline \multicolumn{9}{|c|}{ MLNB-740, Jerry Ferguson porphyry } \\
\hline $\begin{array}{ll}\text { C. } & N+149 \mathrm{~A} \\
\text { D. } & \mathrm{N}+149 \mathrm{Mu} \mathrm{S} A \\
\text { E. } & \mathrm{N}+105-149 \mathrm{~A} \\
\text { F. } & \mathrm{W}+105-149 \mathrm{~A}\end{array}$ & $\begin{array}{l}0.0655 \\
0.0282 \\
0.0167 \\
0.0283\end{array}$ & $\begin{array}{l}366.1 \\
161.5 \\
288.9 \\
257.9\end{array}$ & $\begin{array}{l}25.65 \\
11.90 \\
18.76 \\
16.61\end{array}$ & $\begin{array}{l}6974 \\
3074 \\
1917 \\
2184\end{array}$ & $\begin{array}{r}17.2 \\
18.0 \\
10.4 \\
9.8\end{array}$ & $\begin{array}{l}0.06393 \\
0.06653 \\
0.06413 \\
0.06409\end{array}$ & $\begin{array}{l}0.48282 \\
0.50533 \\
0.48391 \\
0.48433\end{array}$ & $\begin{array}{l}403.0+/-1.5 \\
416.0+/-2.2 \\
401.0+/-2.8 \\
404.6+/-2.7\end{array}$ \\
\hline
\end{tabular}

$\star$ radiogenic $\mathrm{Pb}$, blank corrected. Errors are $2 \sigma / \sqrt{\mathrm{n}}$. $\mathrm{N}=$ non-magnetic at $<1^{\circ}$ side tilt, 1.7 amps on Frantz magnetic separator; $\mathrm{W}=$ weakly magnetic at $<2^{\circ},>1^{\circ}, 1.7$ amps; $\mathrm{M}=$ magnetic at $<5^{\circ}, 1$ amp, and $>2^{\circ}, 1.7$ amps. $A=$ abraded; $M u=$ multifaceted grain; $S=$ single grain.

concordia (Fig. 5a). Fraction A is more concordant; fraction B probably has slight $\mathrm{Pb}$ loss. We therefore assign an age of $419 \pm$ $1 \mathrm{Ma}$ to this sample based on the ${ }^{206} \mathrm{~Pb} /{ }^{235} \mathrm{U}$ age of fraction $\mathrm{A}$.

Sample MLNB-740 is from the Jerry Ferguson porphyry (Appendix 1, Fig. 2).Zircons displaying two different morphologies are present in this sample: elongate, simple prisms with a dipyramid (l:b=2.5:1 to $3: 1)$ and stubby, multifaceted grains (l:b $=1.5: 1)$. Both populations are pale yellow with excellent clarity, contain no cores or visible zoning, and have rare, clear tubes and bubbles. Zircons in fraction F contain rare opaque specks (probably ilmenite).

Three fractions of elongate grains cluster on or near concordia at $401 \mathrm{Ma}$ (Fig. 5b). Fraction E is concordant at $401 \pm 1 \mathrm{Ma}$, which we interpret as the crystallization age of the sample. Fractions $\mathrm{C}$ and $\mathrm{F}$ plot below concordia, suggesting $\mathrm{Pb}$ loss, but their $\mathrm{Pb} / \mathrm{Pb}$ ages are $>401 \mathrm{Ma}$. The result for a single multifaceted grain (D) is concordant at $415 \pm 1 \mathrm{Ma}$ and confirms that the multifaceted grains are xenocrystic. Fractions $\mathrm{C}$ and $\mathrm{F}$ have $\mathrm{Pb} /$ $\mathrm{Pb}$ ages slightly greater than $401 \mathrm{Ma}$ suggesting that these fractions contain a minor xenocrystic component. The xenocrystic part is probably only slightly older than the magmatic part, i.e., comparable to the age of fraction $D$.

\section{DISCUSSION}

The $401 \pm 1$ Ma age (Early Devonian) on the Jerry Ferguson porphyry is geologically reasonable because this intrusion cuts rocks that are paleontologically dated as Gedinnian, but the 419 \pm 1 Ma age for the Mulligan Gulch porphyry appears to contradict the geologic evidence. If the Mulligan Gulch intrusion was more or less syn-sedimentary, as the textural evidence suggests, then its age is paleontologically constrained between the Pridolian LaPlante Formation and the Gedinnian Tobique Group. Therefore, the Mulligan Gulch should have a Pridolian (408-414 Ma) age, rather than a Ludlovian (414-421 Ma) age, based upon its stratigraphic position. However, the age uncertainty on the Ludlow-Pridoli boundary is 12 m.y. (Palmer, 1983) so the 419 Ma age may indicate this boundary is closer to 421 Ma rather than to $414 \mathrm{Ma}$.
The radiometric ages show that felsic plutonism was contemporaneous with felsic volcanism during Late Silurian to Early Devonian time in the Upsalquitch Forks area. The mafic intrusions must be of similar age because (a) mafic and felsic volcanic rocks are interbedded throughout the volcanic pile (Walker and McCutcheon, 1991), and (b) mafic lavas are co-magmatic with mafic intrusions, based upon geochemical similarities (Murphy, 1989).

The mafic and felsic intrusions are syn- to post-tectonic and commonly cut rocks that have a well developed cleavage. For example, some undeformed breccias that are genetically related to mafic intrusions (Ruitenberg et al., 1989; Murphy, 1989) contain foliated clasts of Silurian sedimentary rocks. This means that the Silurian country rocks were already deformed prior to Early Devonian time and furthermore indicates that the Acadian Orogeny started prior to this time. Notably, Hubacher and Lux (1987) have reported post-tectonic intrusions of similar age from northeastern Maine, and Bevier and Whalen (1990) have reported Late Silurian ages from granites located southeast of the present map area. The fact that cleavage is generally better developed in Silurian and older pelitic rocks than it is in Lower Devonian pelitic rocks in the Upsalquitch Forks area (Walker and McCutcheon, 1991), may be relevant to the timing of Acadian deformation. Very likely, this deformation was continuous throughout much of Silurian and Early Devonian time, i.e., deposition occurred in conjunction with deformation.

Volcanism took place during Late Silurian throtigh Early Devonian time and must have occurred in an overall compressional tectonic setting. Within this compressional regime, extensional areas may have existed but there is no $a$ priori reason that the crustal-geochemical signature of these Siluro-Devonian volcanic rocks necessitates a "continental rift environment" as postulated by Dostal et al. (1989). More likely, this volcanism reflects melting of the upper mantle and lower crust, brought on by crustal thickening that resulted from continental collision. Subsequently, rapid erosion of uplifted continental crust in the Middle Devonian resulted in isostatic rebound of hot lower crust, which produced adiabatic crustal melts during the Late Devonian and ultimately led to collapse of the orogen and formation of the 

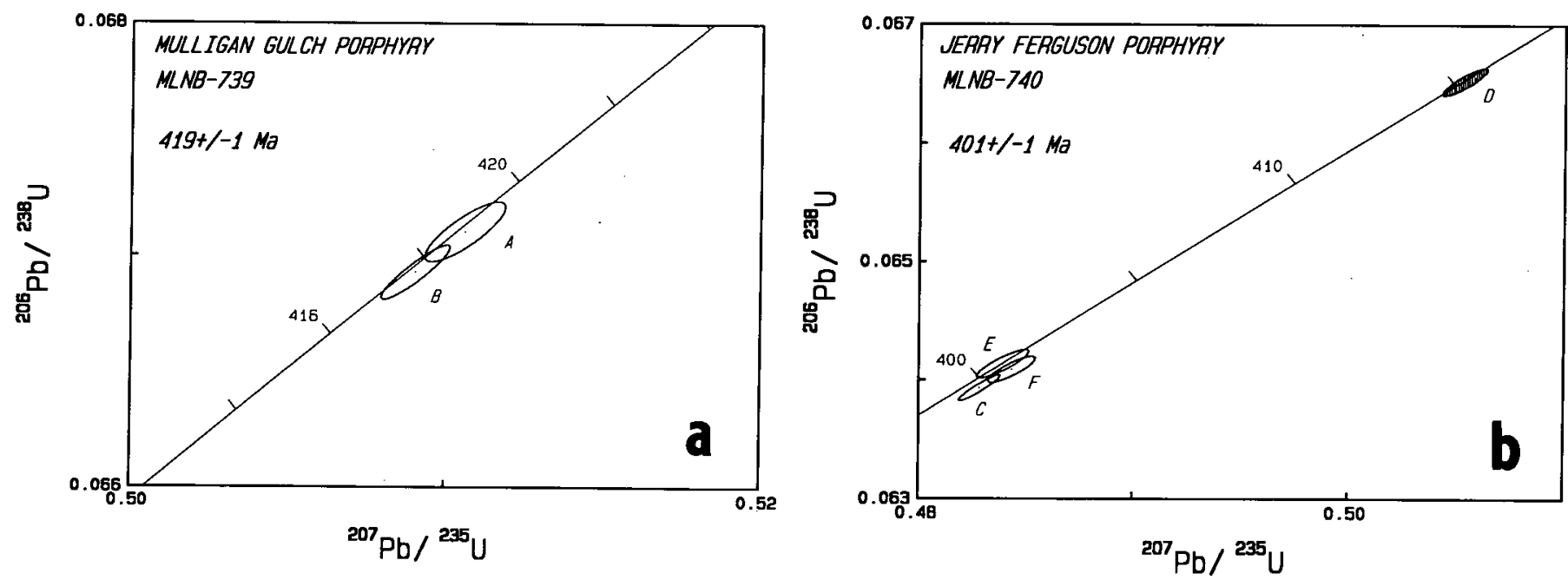

Fig. 5 (a) U-Pb concordia plot for the Mulligan Gulch porphyry. (b)U-Pb concordia plot for the Jerry Ferguson porphyry. Shaded ellipse - multifaceted xenocrystic zircon.

Maritimes Basin in the Carboniferous (McCutcheon and Robinson, 1987).

The spatial association of gold occurrences with intrusive rocks strongly suggests that there is a genetic relationship between the two. Therefore, gold mineralization was probably emplaced intermittently throughout Late Silurian and Early Devonian time. The intrusions were either the direct source of the gold-bearing fluids or the heat source that drove the hydrothermal systems. In either case, gold could have been deposited at any time during the $18 \mathrm{~m} . y$. magmatic episode. This interpretation is supported by the fact that relatively unaltered mafic intrusions cut altered auriferous ones (Mitton, 1988; Adair, 1989).

If the above interpretation is correct, the importance of the RBMF and its splays in controlling the distribution of gold occurrences has been over-emphasized (Pronk and Burton, 1988; Ruitenberg et al., 1989, 1990) because the intrusions are not confined to fault zones. Therefore, it is not surprising that at least one of the RBMF splays, the McCormack Brook Fault (MBF), clearly overprinted iron-carbonate alteration associated with the McCormack Brook East gold showing (occurrence \#4 in Fig. 2).

\section{ACKNOWLEDGEMENTS}

This project was funded by the New Brunswick Department of Natural Resources and Energy under the Canada - New Brunswick Mineral Development Agreement, 1984-1989. We thank the technical staff of the Geochronology Section of the Geological Survey of Canada for their help in generating the analytical data. Reviews by J. Mortensen, R. Wilson and G. Dunning were very helpful and resulted in improvements to the final manuscript. GSC Contribution Number 36590.

ADAIR, R.N. 1989. Report of work McCormack/Ramsay Property Project 4231, Balmoral Parish, Restigouche County, N.B. New Brunswick Mineral Resources Division, Assessment Report 473749. AMI, H.M. 1900. Notes bearing on the Devono-Carboniferous problem in Nova Scotia and New Brunswick. Ottawa Naturalist, 4, pp. 121 127.
ANDREWS, H.N., GENSEL, P.G., and KASPER, A.E. 1975. A new fossil plant of probable intermediate affinities (Trimerophyte Progymnosperm). Canadian Journal of Botany, 53, pp. 1719-1728.

BEVIER, M.L. and WHALEN, J.B. 1990. Tectonic significance of Silurian magmatism in the Canadian Appalachians. Geology, 18, pp. $411-414$.

BOURQUE, P.A. 1987. Silurian stratigraphy and facies, Port-Daniel/ Gascons and Black-Cape areas, southem Gaspe, Quebec. In Centennial Field Guide Volume 5, Northeastern Section of the Geological Society of America. Edited by D.C. Roy. Geological Society of America, Boulder, Colorado, pp. 379-384.

BOURQUE, P.A. and LACHAMBRE, G. 1980. Stratigraphie du Silurien et du Devonien du Sud de la Gaspesie. Quebec Department of Energy and Resources, Special Paper ES-30, 123 p.

BREWER, A.G., PHILPOTT, G.R., and McCUTCHEON, S.R. 1991. Geology and lithogeochemistry of the Charlo River area (parts of $21 \mathrm{O} / 10,21 \mathrm{O} / 15$ and $21 \mathrm{O} / 16$ ), north-central New Brunswick. New Brunswick Department of Natural Resources, Minerals and Energy Division, Open File 91-2, 150 p.

CLARKE, J.M. 1909. The Dalhousie Formation. In Early Devonic history of New York and eastem North America. New York State Museum, Memoir 9, Part 2, pp. 7-51.

DINELEY, D.L. and WILLIAMS, B.P.J. 1968. The Devonian continental rocks of the lower Restigouche River, Quebec. Canadian Journal of Earth Sciences, 5, pp. 945-953.

DOSTAL, J., WILSON, R.A., and KEPPIE, J.D. 1989. Geochemistry of Siluro-Devonian volcanic rocks in northern and central New Brunswick (Canada): tectonic implications. Canadian Joumal of Earth Sciences, 26, pp. 1282-1296.

FITZPATRICK, D. 1986. Report of work McCormack/Ramsay Property Project 4294, Restigouche County, New Brunswick. New Brunswick Mineral Resources Division, Assessment Report 473301.

FYFFE, L.R. 1986. A recent graptolite discovery from the Foumier Group of northern New Brunswick. In Eleventh Annual Review of Activities. Edited by S.A. Abbott. Mineral Resources Division, New Brunswick Department of Natural Resources and Energy, Information Circular 86-2, pp. 43-45.

FYFFE, L.R. and FRICKER, A. 1987. Tectonostratigraphic terrane analysis of New Brunswick. Maritime Sediments and Atlantic Geology, 23, pp. 113-122.

GREINER, H.R. 1967. Silurian-Devonian relationships of the Charlo 
map-area, New Brunswick. In International Symposium of the Devonian. Edited by D.H. Oswald. Alberta Society of Petroleum Geologists, 2, pp. 973-979

HUBACHER, F.A. and LUX, D.R. 1987. Timing of Acadian deformation in northeastern Maine. Geology, 15, pp. 80-83.

KROGH, T.E. 1982. Improved accuracy of U-Pb ages by the creation of more concordant systems using an air abrasion technique. Geochimica et Cosmochimica Acta, 46, pp. 637-649.

LEE, H.J. and NOBLE, J.P.A. 1977. Silurian stratigrapl-y and depositional environments: Charlo - Upsalquitch Forks area, New Brunswick. Canadian Journal of Earth Sciences, 14, pp. 2533-2542.

McCUTCHEON, S.R. and ROBINSON, P.T. 1987. Geological constraints on the genesis of the Maritimes Basin, Atlantic Canada. In Sedimentary basins and basin forming mechanisms. Edited by $\mathbf{C}$. Beaumont and A.J. Tankard. Canadian Society of Petroleum Geologists, Memoir 12, pp. 287-297.

McGREGOR, D.C. 1961. Spores with proximal radial pattern from the Devonian of Canada. Geological Survey of Canada, Bulletin 76, 11 p.

MITTON, B. 1988. Report of work McCormack/Ramsay Property Project 4231. New Brunswick Mineral Resources Division, Assessment Report 473541.

MURPHY, R.B. 1989. Geochemistry of the Siluro-Devonian mafic volcanic rocks and associated gabbroic intrusions, Upsalquitch Forks area, New Brunswick. Unpublished M.Sc. thesis, Acadia University, 274 p.

PALMER, A.R. 1983. The Decade of North American Geology geologic time scale. Geology, 11, pp. 503-504.

PARRISH, R.R., RODDICK, J.C., LOVERIDGE, W.D., and SULLIVAN, R.W. 1987. Uranium-lead techniques at the geochronology laboratory, Geological Survey of Canada. In Radiogenic age and isotopic studies: Report 1. Geological Survey of Canada, Paper 87 2. pp. 48-56.

PHILPOTT, G.R. 1988. Precious-metal and geological investigation of the Charlo River area, New Brunswick. In Thirteenth annual review of activities, project resumes, 1988. Edited by S.A. Abbott. New Brunswick Department of Natural Resources and Energy, Minerals and Energy Division, Information Circular 88-2, pp. 20 31.

PRONK, A.G. and BURTON, D.M. 1988. Till geochemistry as a technique for gold exploration in northem New Brunswick. New Brunswick Canadian Mining and Metallurgical Bulletin, 81, pp. 90-98.

RODDICK, J.C. 1987. Generalized numerical error analysis with applications to geochronology and thermodynamics. Geochimica et Cosmochimica Acta, 51, pp. 2129-2135.

RUITENBERG, A.A., MOCUTCHEON, S.R., WATTERS, S.E., McLEOD, M.J., BURTON, D.M., and HOY, D. 1989. Field guide to gold occurrences in New Brunswick. New Brunswick Department of Natural Resources and Energy, Minerals and Energy Division, Field Guidebook No. 1, 63 p.

RUITENBURG, A.A., JOHNSON, S.C., and FYFFE, L.R. 1990. Epigenetic gold deposits and their tectonic setting in the New Brunswick Appalachians. Canadian Mining and Metallurgical Bulletin, 83, pp. 43-55.

RUST, B.R., LAWRENCE, D.A., and ZAITLIN, B.A. 1990. The sedimentology and tectonic significance of Devonian and Carboniferous terrestrial successions in Gaspe, Quebec. Atlantic Geology, 25, pp. 1-13.

SPRAY, J.G., FLAGLER, P.A., and DUNNING, G.R. 1990. Crystalli- zation and emplacement chronology of the Fournier oceanic fragment, Canadian Appalachians. Nature, 344, pp. 232-235.

STACEY, J.S. and KRAMERS, J.D. 1975. Approximation of terrestrial lead evolution by a two stage model. Earth and Planetary Science Letters, 26, pp. 207-221.

STEIGER, R.H. and JÄGER, H. 1977. Subcommision on geochronology: convention on the use of decay constants in geo- and cosmochronology. Earth and Planetary Science Letters, 36, pp. 359-362.

ST. PETER, C. 1978a. Geology of parts of Restigouche, Victoria and Madawaska counties northwestern New Brunswick. New Brunswick Department of Natural Resources, Report of Investigation No. 17,69 p.

1978b. Geology of head of Wapske River, map-area J-13. New Brunswick Department of Natural Resources, Mineral Resources Branch, Map Report 78-1, 24 p.

van STAAL, C.R. and FYFFE, L.R. In Press. The New Brunswick Dunnage and Gander zones. In The Appalachian/Caledonian Orogen. Canada and Greenland. Coordinated by H. Williams. Decade of North American Geology, Volume F-1.

van STAAL, C.R. and LANGTON, J.P. 1990a. Geology of Ordovician massive sulphide deposits and their host rocks in northem New Brunswick. In Field guide to massive sulphide deposits in northem New Brunswick. Edited by L.R. Fyffe. New Brunswick Department of Natural Resources and Energy, Minerals and Energy Division, pp. 15-41.

1990b. Geology of Ordovician massive sulphide deposits and their host rocks in northern New Brunswick. In Mineral deposits of New Brunswick and Nova Scotia [Field Trip 2]. Edited by D.R. Boyle. Eigth IAGOD Symposium Field Guide Book, Geological Survey of Canada, Open File 2157, pp. 1-21.

van STAAL, C.R., LANGTON, J.P., and SULLIVAN, R.W. 1988. A U$\mathrm{Pb}$ zircon age for the ophiolitic Deveraux(sic) Formation, Elmtree Terrane, northeastem New Brunswick. Geological Survey of Canada, Paper 88-2, pp. 37-40

WALKER, J.A. and McCUTCHEON, S.R. 1991. Geology and lithogeochemistry of Upsalquitch Forks (NTS 21 O/10), north-central New Brunswick. New Brunswick Department of Natural Resources, Minerals and Energy Division, Open File 91-3, 130 p.

WILSON, R.A. 1990. Geology of New Denmark - Salmon River area, Victoria County, New Brunswick (parts of NTS $21 \mathrm{~J} / 13,21 \mathrm{~J} / 14$, 21 O/3, 21 O/4). New Brunswick Department of Natural Resources, Minerals and Energy Division, Report of Investigation No. 23, 67 p.

\section{APPENDIX 1: SAMPLE LOCATIONS}

Sample MLNB-739 (Mulligan Gulch porphyry) was collected $2 \mathrm{~km}$ west-southwest of the intersection of the Dalhousie Road with the unnamed haulage road that leads west from Mulligan Gulch Camp (NTS 21 O/10-204). The sample was taken from subcrop (felsenmeer) along a pulp-road on the south side of the highest hill in the area.

Sample MLNB-740 (Jerry Ferguson porphyry) was collected $700 \mathrm{~m}$ east-southeast of the Dalhousie Road bridge over Southeast Upsalquitch River (NTS 21 O/10-404). The sample was taken from a large outcrop along the north side of the bushroad that follows the north side of the river. The outcrop is beside a small unnamed stream that enters the river on the opposite bank from Jerry Ferguson Brook. 